(6) The coefficients should possess whatever other properties may be required for the work in connexion with which they are to be used.

Elongation and tabularity probably satisfy condition (3) better than do the acicularity and isoproportionality coefficients. But subjective impressions are much less sensitive to slight changes of shape than are the numerical values of $E$ and $T$; and the calcula. tion of these coefficients involves a considerably greater number of operations than is required for the acicularity and isoproportionality coefficients. With regard to condition (6), the two systems are probably suited to different purposes. Thus on my system a mixture of tabular square prisms and elongated ones would always give mean coefficients corresponding to a square prism (or to a cube if the values were appropriately distributed), whereas on Mr. Tomkeieff's system it would not.

Field Cottage,

E. J. W. WhitTakeR.

Windlehurst Road,

High Lane,

Stockport.

\section{Chemistry at the Older Universities}

IN an article in Nature of February 10 on "Chemistry at the Older Universities of Britain during the Eighteenth Century", Dr. Archibald Clow repeats a number of assertions of a highly flattering character which have been made from time to time regarding John Mayow, by Beddoes, Yeats, Gotch, Gunther and others; statements which it is surely time to eliminate from the history of science. Dr. Clow says that Mayow's "De Sal-nitro et Spiritu nitro-aereo heralded the later discovery of oxygen", and he quotes, apparently with approval, Gunther's view that Mayow was the "greatest chemist whom Oxford ever produced". Also he says that "Mayow was not an associate of Boyle; indeed they seem to have been mutually unaware of each other's work, and Mayow's contributions remained hidden for many years".

In an article published some time ago entitled "John Mayow in Contemporary Setting"', I pointed out that these views-as well as many others held regarding Mayow-are very erroneous; and that Mayow's work, far from being independent of Boyle's, was merely a pale reflexion from it. Mayow, in fact, mentions Boyle fairly often, and states that some of his experiments were similar to those of Boyle. Part of his endeavour was to show that what we call nitric oxide obeyed Boyle's Law, and although here he does not mention Boyle he very probably thought the connexion to be so obvious as not to require it. That Mayow's work was not hidden at all is shown by the fact that it received extensive review in the Phil. Trans. at the time of its publication.

On the other hand, that Boyle was aware of Mayow seems to be clearly indicated by the fact that Oldenburg, in a letter dated July 10, 1674, writing to Boyle, says: "I hear some very learned and knowing men speak very slightly of the quinque Tractatus of J. M., and a particular friend of yours and mine told me yesterday, that as far as he had read him, he would shew to any impartial and considering man more errors than one in every page" 2 . All who have really studied Mayow's work are pretty certain to agree with these "learned and knowing men". It is time that our perspective regarding Mayow was finally and definitely readjusted.

University of Glasgow.

T. S. Patterson.

1 Isis, 15, 47, 504 (1931).

'Boyle's "Works", 5, 395b (1744).

IT has been very kindly pointed out to me by Dr. K. R. Webb, of Southampton, that I have done less than justice to Cambridge chemistry by omitting to mention that it was I. Milner (1750-1820) who, although Jacksonian professor of natural philosophy and not a chemist per se, observed in 1788 that ammonia passed over heated manganese dioxide is converted into red fumes which dissolve in water to form nitric acid. This oxidation of ammonia now effected catalytically by atmospheric oxygen is the basis of the modern commercial method of preparing nitric acid. Both Milner and his successor, F. J. H. Wollaston (1762-1823), taught chemistry and published plans of their courses.

Other minor points are 'Robinson', p. 161, col. 2, line 38, should read 'Robison'; 'Vagani' should read 'Vigani' throughout; the intrusive comma between Cullen and went, p. 160, col. 2, line 41, should be deleted; the first of R. Watson's Essays appeared three years earlier than stated; finally, although R. T. Gunther in "Early Science in Cambridge" (p. 225) gives the date 1741, apparently Mickleburgh (or Mickleborough) held office until 1756.

On the other hand, as far as Oxford is concerned, following the long line of historians from Beddoes to Gunther I credited John Mayow with being one of the great luminaries of early Oxford chemistry. That this is not so has been discussed by Prof. T. S. Patterson, and all chemists interested in the early history of their subject should refer to his masterly analysis referred to above.

Department of Chemistry, Marischal Colloge, Aberdeen.

Archibald Clow.

\section{Exypnopia}

From time to time I have experienced, immediately

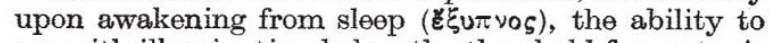
see with illumination below the threshold for scotopic vision. This power of seeing in the dark, which is transient, is quite different from scotopic (twilight) vision: the colour red can be distinguished; and the field of vision is small. I think that the portion of the retina employed is the macula lutea, a part which is generally regarded as being night-blind. That the illumination was really below the threshold for scotopic vision is confirmed by my wife who, on at least two of the several occasions, observed that the room (which was 'blacked-out') was pitch-dark.

The phenomenon appears to me to be an interesting survival of a faculty which must formerly have been of considerable value to man, a faculty analogous to that of pricking up the ears, which some of us-doubtless the less highly civilized-still retain.

The King's Lodge,

A. F. Dufton.

Hunton Bridge,

Hertfordshire.

March 31. 